\title{
Tunja: nociones de imagen
}

\section{Artículo de investigación*}

\section{Yulieth Guerrero Nieto}

syguerrero@uniboyaca.edu.co.

Universidad de Boyacá, Colombia

Recibido: 12 de mayo de 2017

Aprobado: 20 de julio de 2017

Cómo citar este artículo: Nieto, Guerrero Yuliet. (2018) Tunja: Nociones de imagen. Calle14: revista de investigación en el campo del arte 13 (23) pp. 102-121. DOI: https://doi.org/10.14483/21450706.12991

*Derivado de la investigación titulada: Imagen de ciudad: Nuevo Patrimonio 


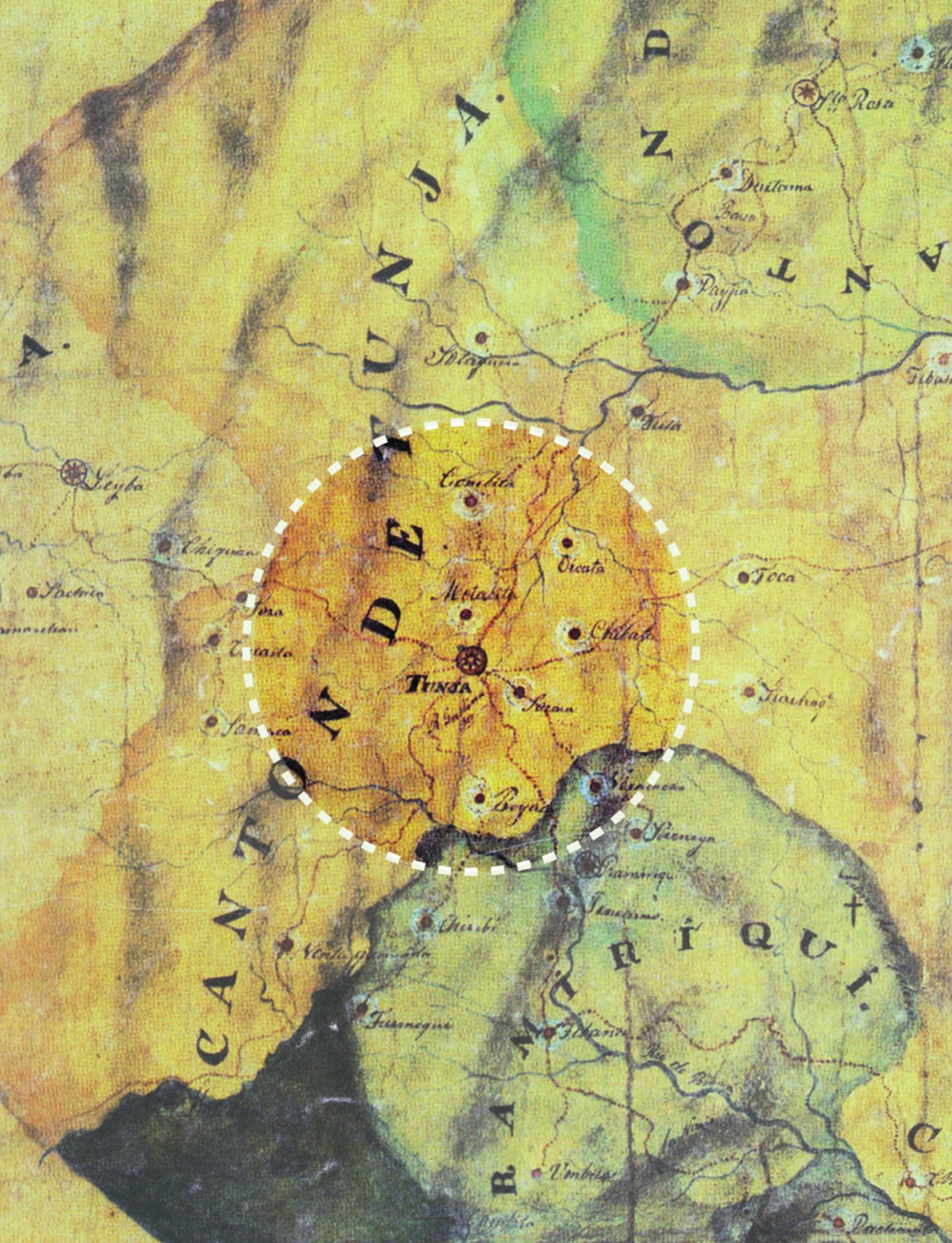




\title{
Resumen
}

El presente artículo de reflexión hace parte de la investigación "Imagen de ciudad: Nuevo patrimonio", cuya pregunta central fue: ¿Cómo se evidencia la relación habitante-ciudad a partir de una imagen recreada en la dinámica urbana actual? El documento se refiere a cómo se ha expresado la imagen de Tunja, tanto física como imaginariamente y cómo estas expresiones evidencian algunas ideas de ciudad. De manera que se hace una revisión desde las primeras imágenes de la ciudad, sus mapas, sus descripciones, sus acercamientos desde la técnica, hasta el nuevo mapa de ciudad que plantean las nuevas redes de información, por medio de contrastes entre las nociones de ciudad expuestas en las imágenes a través de la historia y la realidad física; este conjunto de ideas cartográficas, históricas, tecnológicas, fotográficas e imaginarias permiten una lectura de una ciudad indefinible desde una sola perspectiva y establecer una visión conjunta y diversa de la misma.

\section{Palabras claves}

Imagen, ciudad, mapa, imaginario, historia, cartografía.

\section{Tunja: notions of the image}

\begin{abstract}
The present article of reflection is part of the research "Image of the City: New Heritage", whose central question was: How is the relation between inhabitant and city based on an image recreated in the current urban dynamics? The document refers to how the image of Tunja has been expressed, both physically and imaginatively, and how these expressions evidence some ideas of the city. Thus, a review is made, from the first images of the city, its maps, its descriptions, its approaches from the technical view, to the new city map that the new information networks propose, by means of contrasts between the notions of city exposed in the images through history and physical reality; this set of cartographic, historical, technological, photographic and imaginary ideas allows a reading of an indefinable city from a single perspective and establish a joint and diverse vision of it.
\end{abstract}

\section{Keywords}

Image, city, map, imaginary, history, cartography.

\section{Tunja : notions de l'image}

\section{Résumé}

Le présent article de réflexion fait partie de la recherche «Image de la Ville : Nouveau Patrimoine», dont la question centrale était : Comment la relation entre habitant et ville reposet-elle sur une image recréée dans la dynamique urbaine actuelle ? Le document se réfère à la façon dont l'image de Tunja a été exprimée, à la fois physiquement et imaginativement, et comment ces expressions témoignent de certaines idées de la ville. Ainsi, une revue est faite des premières images de la ville, de ses cartes, ses descriptions, ses approches au technique, à la nouvelle carte de la ville que proposent les nouveaux réseaux d'information, au moyen de contrastes entre les notions de ville exposées dans les images à travers I'histoire et la réalité physique ; cet ensemble d'idées cartographiques, historiques, technologiques, photographiques et imaginaires permet de lire une ville indéfinissable à partir d'une seule perspective et d'en établir une vision commune et diversifiée.

\section{Mots clés}

Image, ville, carte, imaginaire, histoire, cartographie. 


\section{Resumo}

O presente artigo de reflexão faz parte da pesquisa "Imagem da Cidade: Novo Patrimônio", cuja questão central foi: como a relação entre habitante e cidade é baseada em uma imagem recriada na atual dinâmica urbana? 0 documento refere-se a como a imagem de Tunja foi expressa, tanto física como imaginativamente, e como essas expressões testemunham certas idéias da cidade. Assim, uma revisão é feita a partir das primeiras imagens da cidade, seus mapas, suas descrições, suas abordagens da visão técnica, para o novo mapa da cidade que as novas redes de informação propõem, por meio de contrastes entre as noções de cidade expostas nas imagens através da história e da realidade física; Este conjunto de estudos cartográficos, históricos, fotográficos e imaginários permite a leitura de uma cidade indefinível a partir de uma única perspectiva e estabelecendo uma visão conjunta e diversa da mesma.

\section{Palavras-chave}

Imagem, cidade, mapa, imaginário, história, cartografia.

\section{Tunja: imasami karka iuiari}

\section{Maillallachiska:}

Kai kilkaska iuiachi kumi sug tapuikunami " sug atun puglumanda" musu "iukai", chasami kai tapuikuna karka ¿ imasa kai kaugsagkuna chi altun puglupi chasami imasami ka suma rigcha i kunapunchakuna kaskasina? Kai kilkaska nikami imasami kai alpa suti Tunja, imasami ka muskuipisina i iuiariipisina chasami kai kawachimi kai atun puglumanda iuiariikuna. Chasami kawankunami imasami karka ñugpata kai suti atun puglumanda, sug iuia pangapi llunchiskapi imasami karka paipa. Kaiaia, i musu pangapi imasami karka paipa kaiaia, i musu pangapi imasami karka kai atun puglukaskamanda i imasami paikuna imasami ka tukun iachikuna, chasami imasami kagta kai iuiaikunawa kai atun puglumanda. Kawachispa antiwamanda i parlukunamanda imasami ka chi kunapunchamanda, kai iuiakuna ruraskapi chi kilkaikunapi sugregcha parlu i suma iuiarirpa kawachingapa i iuiarispa chasami kawachii sug luarmanda suma kagta suglla kawaspa i kawaspa sug kawaiwa chasaiatata.

\section{Rimangapa Ministidukuna:}

Imasami karka, atun puglu, sug iura pangapi llunchiska, iuiarispa, parlukuna, kartografiapi. 


\section{Ciudad e imagen}

"Una imagen es genuinamente simbólica por su propia estructura"

(Pérgolis, 1998: 72)

¿Qué es una imagen? Según el concepto más directo, una imagen es la representación de una cosa en su ausencia, en ese caso "la imagen por lo general no es más que indicadora de una cosa y como tal indicación o signo solo existe en la mente y no en la realidad"; la imagen, como signo, "es siempre separable de lo real, una representación en la mente" (Kogan, 1986:1). Si se apela al concepto de imagen como signo, y al de signo, cuyo significado más amplio fue establecido primariamente por los estoicos como "algo que está en lugar de algo" surge la pregunta sobre ¿qué es entonces lo que está en lugar del objeto real llamado 'ciudad'?

La imagen como unidad significativa se construye, dice Kogan (1986), a partir de la imaginación, es decir hay una voluntad creadora que produce, que configura la imagen, en este caso en particular, existe entonces una voluntad creadora que produce la imagen de la ciudad.

Aunque la ciudad no es algo que necesariamente está ausente, aun así, por la magnitud física de este lugar (la ciudad) todo ciudadano requiere formar en su mente una idea, una imagen mental (Lynch, 1984) que le permita comprender el espacio que habita. la existencia de mapas, fotografías, etc., evidencian la necesidad de generar imágenes de la ciudad, sean estas de carácter cartográfico y geográfico que en muchos casos adquieren un carácter abstracto pues siempre ofrecen una visión bidimensional de la ciudad, o sean estas parte de los imaginarios individuales y colectivos, es decir otro tipo de imágenes, que abarcan ideas, percepciones, sensaciones, etc.

¿Cómo se construye una imagen de la ciudad? En primer lugar, dicha imagen se construye a partir de categorías que tienen que ver tanto con los aspectos visibles de la misma, como con aquellos que se forman en la mente de los ciudadanos; en los dos casos intervienen aspectos históricos, morfológicos, físicos, culturales, estéticos, simbólicos. De este modo, una imagen básica es la ofrecida por el mapa y sus transformaciones gráficas a través del tiempo, también está la imagen de la ciudad desde su conformación física, su dinámica socioeconómica, su noción de progreso, estas imágenes alimentan y configuran diferentes percepciones en el ciudadano, así mismo la ciudad como hecho espacial y de interacción cotidiana entre lo físico y lo humano y en la cual el ciudadano hace sus intervenciones de acuerdo a sus actividades (habitar, trabajar, descansar y circular) ${ }^{1} \mathrm{y}$ en donde el ente administrativo como 'acto' político también ejerce su poder de intervención (infraestructura, equipamiento, espacio público, etc.) promueve la creación de una imagen que se mueve entre los términos de lo funcional hasta lo estético. Esta imagen, que se produce desde la intervención, es la imagen que proyecta la ciudad; por otra parte, está la imagen de ciudad que se conforma a partir de los imaginarios colectivos. Esa otra imagen que no es física en un mapa, que no es construida mediante intervenciones sino es aquella imagen simbólica, percibida y expuesta por el colectivo o bien sea inventada para algo. Por otra parte, hay también imágenes encontradas, elaboradas y soñadas de una ciudad mundo. Todas estas visiones conforman la idea de ciudad, de los que la habitan, de los que la ven de lejos, de los que la usan y de los que a veces la aman. "Una ciudad es un mundo", si amas a uno de sus habitantes, menciona Pérgolis (1998) citando a Lawrence Durrel. La imagen de la ciudad es por tanto una imagen también de cada mundo.

\section{La imagen del mapa (técnica apropiada)}

Mapa: (Del b. lat. mappa, toalla, plano de una finca rústica). m. Representación geográfica de una parte de la superficie terrestre, en la que se da información relativa a una ciencia determinada. Mapa lingüístico, topográfico, demográfico. (Diccionario de la Real Academia de la Lengua)

El mapa como representación geográfica sobre una superficie plana, es el primer signo reconocible de la ciudad, el mapa surge con la necesidad de representar el territorio, con la necesidad de hacer comprensible de alguna manera el territorio dominado, con la necesidad imperante de afirmar dominio, de determinar lugares, de identificar, incluso de nominar, así el topos (el lugar) que requiere ser asible de alguna manera es fácilmente entendible a partir de un mapa, de una representación, esa necesidad conservada a través del tiempo responde claramente a cómo se puede comprender la extensión y la forma de algo inmenso como lo es la geograficidad de una superficie del territorio.

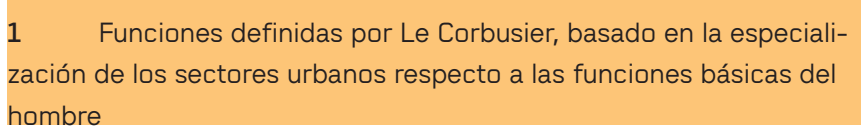


La imagen de la ciudad planimétrica condensa la expresión de las necesidades de dominio, definición, localización, ocupación de un lugar con relación a un marco general (provincia, estado, nación, etc.). Esa necesidad de ubicación y de reconocimiento es clave para la existencia pues conlleva la posibilidad de que en cualquier parte del mundo cualquier persona se haga una 'idea' de un sitio específico a través de un atlas, de un libro de mapas, libro que en este momento particular ya no es solo analógico sino digital.

Como propósitos claros de la representación planimétrica se pueden mencionar: determinar una ubicación dentro de un contexto, describir características físicas, presentar de manera comprensible una extensión geográfica, elaborar un concepto gráfico de una idea, presentar una mirada desde arriba por fuera del objeto representado, afirmar y sustentar una nacionalidad, una ciudadanía, incluso una idea de dominio y poder y generar una idea de reconocimiento propio y ante los demás.

Los diversos mapas de un lugar generan una imagen histórica y gráfica sobre las maneras de representar la ciudad, ofrecen obviamente una noción de crecimiento de transformación de la forma urbana, una concepción entre las aproximaciones a lo real desde diferentes momentos y diferentes percepciones.

\section{La imagen cartográfica de Tunja}

Las representaciones de la ciudad surgen, como se anotó antes, como respuesta a necesidades claras de reconocimiento y existencia. Las primeras nociones de la existencia de Tunja como un territorio son mostradas en las cartografías de la provincia de Santa Fe de 1586 allí se aprecia la idea de la ciudad más como un territorio, pues se mencionan y señalan los términos de Tunja, vale la pena recordar que a la llegada de los españoles, el reino Muisca era visto según las palabras del conquistador y fundador Gonzalo Jiménez de Quesada así: "Este Nuevo Reino se divide en dos partes o dos provincias; la una se llama de Bogotá, la otra, de Tunja, y así se llaman los señores de ella del apellido y tierra. Cada uno de estos dos señores son poderosísimos de grandes señores y caciques que le son sujetos" Tomado del Epítome de Gonzalo Jiménez de Quesada" (Martínez, 1967: 41). Así esta primera referencia está dada en relación a Bogotá, como se verá posteriormente la imagen de Tunja estará marcada desde siempre por su cercanía y tensiones con la capital del país.
Como se observa en la imagen 1, muchas de las poblaciones aledañas a la actual Bogotá subsisten hoy en día, Tunja es señalado como territorio vecino de Santa Fe indicado en el dibujo original con una mano con el índice extendido hacia oriente.

Al lado de la representación de la provincia de Santa fe, Don Diego de Torres Cacique de Turmequé, elabora también la representación de la provincia de Tunja en el mismo año, (imágenes 3 y 4) y allí aparece señalado el nombre de ciudad de Tunja con su representación icónica desde entonces, de la iglesia principal, al parecer distintivo inequívoco del grado de ciudad en las fundaciones hispánicas.

Aunque en esta primera referencia cartográfica que sobre Tunja existe, aparece localizada la ciudad inscrita dentro de un territorio regional, no nos dice nada del trazado urbano, pero si indica un principio de nominación bastante importante, ya que se nombra como 'Ciudad', este hecho denota ya un sentido urbano, pues el sitio urbano lo definieron las gestas fundacionales como la ciudad, al respecto Carlos Martínez (1967) dice:

El sitio o porción de suelo asignado al germen urbano, es el factor que interviene más decisivamente en el carácter, funciones y desarrollo de la ciudad. El sitio no es una porción territorial aislada, es parte integrante e inseparable económicamente del medio geográfico o región circundante. Estos dos apartes de la naturaleza, sitio y región, que en las tierras baldías se presentan confundidos bajo una misma noción territorial, se disocian en el momento en que el hombre decide urbanizar una de las partes. Aparecen así súbitamente de la nada, calles, plazas, solares y casas, es decir el sitio urbano, en contraste con lo rural o espacio regional. El enlace o vínculo vivificante de uno y otro es el camino. Sin un camino no se puede concebir la notable decisión del fundador (68).

El sitio urbano se define dentro de lo que Jaime Salcedo (1996) llama los procesos fundacionales. Dichos procesos comprendían cuatro aspectos básicos: la elección del sitio, la toma de posesión, la delimitación de la plaza, y la designación del solar de la iglesia. Por eso no es fortuito que en estas imágenes la ciudad aparezca representada bajo la imagen de una iglesia: la ciudad es la iglesia.

Si se avanza en el tiempo, los registros cartográficos llevan al plano de Tunja de 1623, no sin antes pasar por 

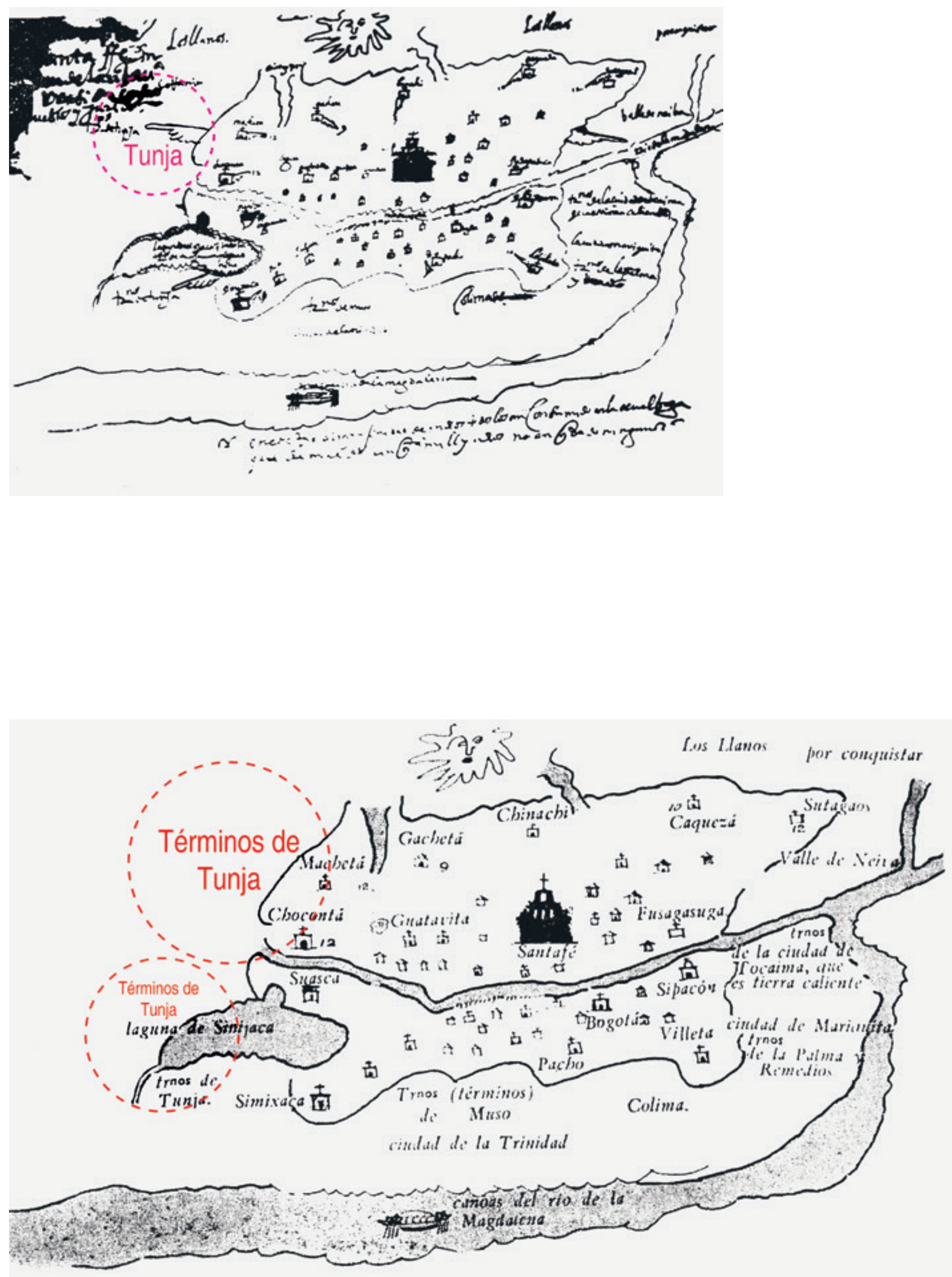

Imagen 1. Documento cartográfico que representa la provincia de Santa Fé. 1586. Elaborado por el cacique Don Diego de Torres (arriba) y Reconstrucción de Carlos Martínez (abajo). Fuente. Martínez, Carlos. Apuntes sobre el urbanismo en el nuevo reino de Granada. Pág. 38/39 


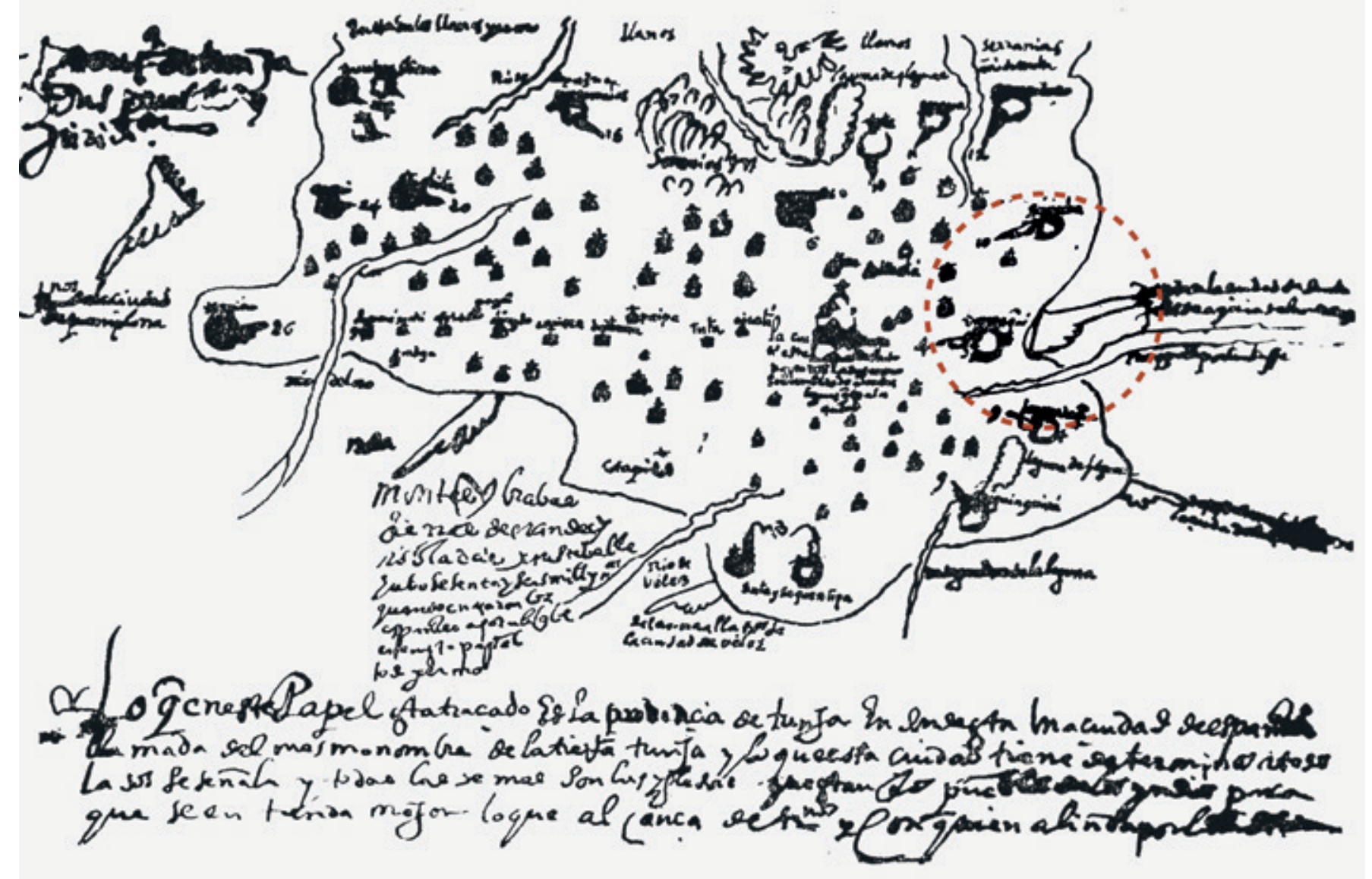

Imagen 3. Documento cartográfico que representa la provincia de Tunja. 1586. Elaborado por el cacique Don Diego de Torres. Fuente: Cartografía Histórica de los territorios Boyacenses. Banco de la República. Área Cultural Tunja. 2003 Pág. 9

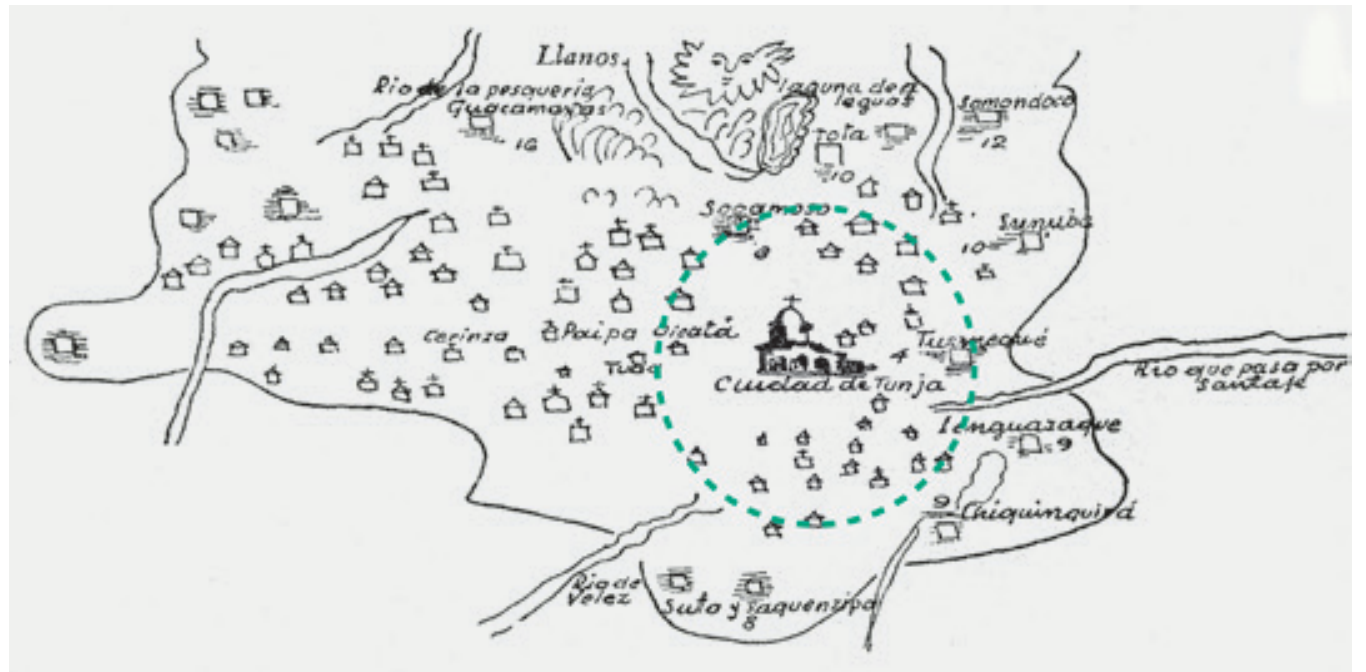

Imagen 4. Reconstrucción de Carlos Martínez del dibujo de Diego de Torres de 1586. Fuente: Cartografía Histórica de los territorios Boyacenses. Banco de la República. Área Cultural Tunja. 2003 Pág. 10 

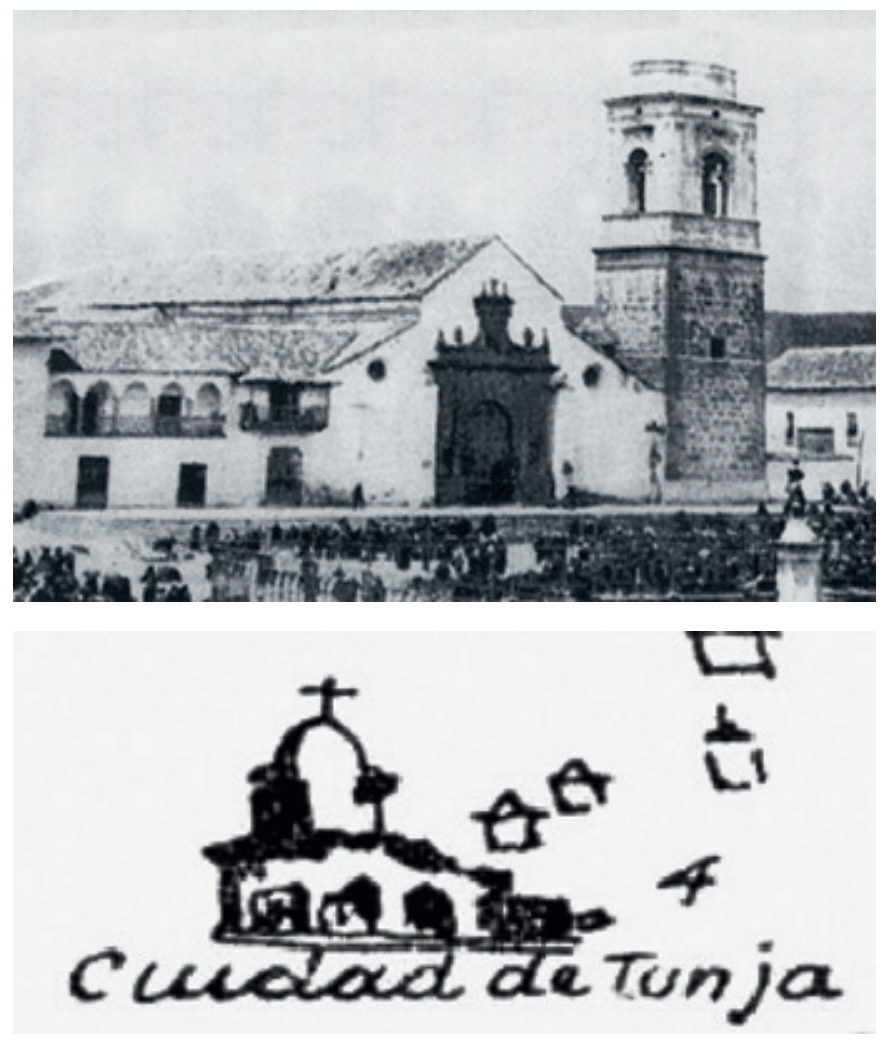

Imagen 5. Fachada original de la catedral de Tunja vs la imagen de la iglesia de Diego de Torres. Fuente: Corradine Angulo. La Arquitectura en Tunja. Academia Boyacense de Historia- SENA. Bogotá 1990. Pág. 56

la descripción de la ciudad en 1610. Estas dos informaciones cruzadas son la segunda referencia para una la reconstrucción de la imagen de ciudad en el Siglo XVII.

La descripción de 1610 es el resultado de la exigencia de la Corona Española a principios del Siglo XVII de dar respuesta a un interrogatorio de 350 preguntas para establecer, con base en las respuestas, un concepto sobre la situación y las necesidades de las provincias en América, la ciudad se definió así: “Tunja tenía siete calles; una plaza principal y dos placetas: la de San Francisco y la de San Agustín, ...la ciudad se había iniciado por cuadras cerradas; en cada una de ellas, cuatro solares que fueron repartidos, y cada cuadra tenía por frente ciento cincuenta pasos." (Academia Boyacense de Historia: 1244) La descripción también menciona los templos y similares, datos que acercan mucho más a un plano real de la ciudad en esa época: “Tunja dependía del Arzobispado de Santa Fe; tenía cuatro templos: Santiago, San Francisco, Santo Domingo, San Agustín; dos conventos de religiosas: Santa Clara la Real, y la Concepción; y las ermitas de San Laureano, Santa Bárbara y Las Nieves, como también la Capilla del Hospital" (Academia Boyacense de Historia: 1246)
En 1610 la ciudad contaba con 71 años de fundada. En la reconstrucción (Imagen 6) se observa la estructura urbana primigenia de la ciudad cuya definición está dada completamente por las construcciones de carácter religioso, coherente esto con la misión evangelizadora de la gesta fundacional.

Posteriormente se encuentra ya como imagen, el plano de 1623 (Imagen 7) cuyo valor radica en que por vez primera la ciudad tiene un plano urbano y al parecer existe de hecho una noción de planeación. Este plano provoca ciertos cuestionamientos; probablemente incluye, como se indicó anteriormente, una insinuación de un trazado futuro, pues si se observa hacia el oriente aparece en términos de nomenclatura de hoy, una posible carrera 5, con cuadras cuadradas lo que topográficamente es improbable; por otra parte, el límite hacia el occidente sería la actual carrera 15, que apenas se insinúa en las fotografías aéreas de 1939. Hacia el norte se observa igualmente reticulado lo que hoy es el parque Santander y como si el barrio Popular existiese, cosa poco probable al cruzar la información de la citada descripción de 1610 . Por lo tanto, lo que representa en realidad el plano de 1623 es una intención de planeación urbana que sin duda desconocía o no le interesaba tener en cuenta los accidentes topográficos, pero con una clara intención de plantear una versión planimétrica de la ciudad fundada.

Otro elemento de este plano es el tratamiento compartido entre planta y alzado. Es posible que, aunque se careciera de nociones especializadas sobre técnicas de representación planimétrica, la intención manifiesta fuese reportar en un solo dibujo los datos exactos de la ciudad, en cuanto predios existentes, lotes baldíos, incluso alturas y dignidades de las edificaciones.

Pero como se ve en el plano actual del centro de la ciudad (Imagen 8), algunos de los aspectos del dibujo de 1623 pueden ser imaginados o supuestos, el dibujante ha debido tomarse algunas licencias, pues no podía la ciudad ser tan grande a tan solo 84 años de fundada y a tan solo 13 años de la descripción anterior, Jame Salcedo anota que en muchas de las representaciones antiguas hubo un interés en mostrar una ciudad un tanto utópica en contraposición a la ciudad real, es decir la ciudad que se percibía entonces probablemente era más grande de lo que era en realidad.

Al sobreponer la información básica de 1623 sobre un plano actual (imagen 8), se ve claramente que el tejido urbano del dibujo no corresponde a los accidentes 


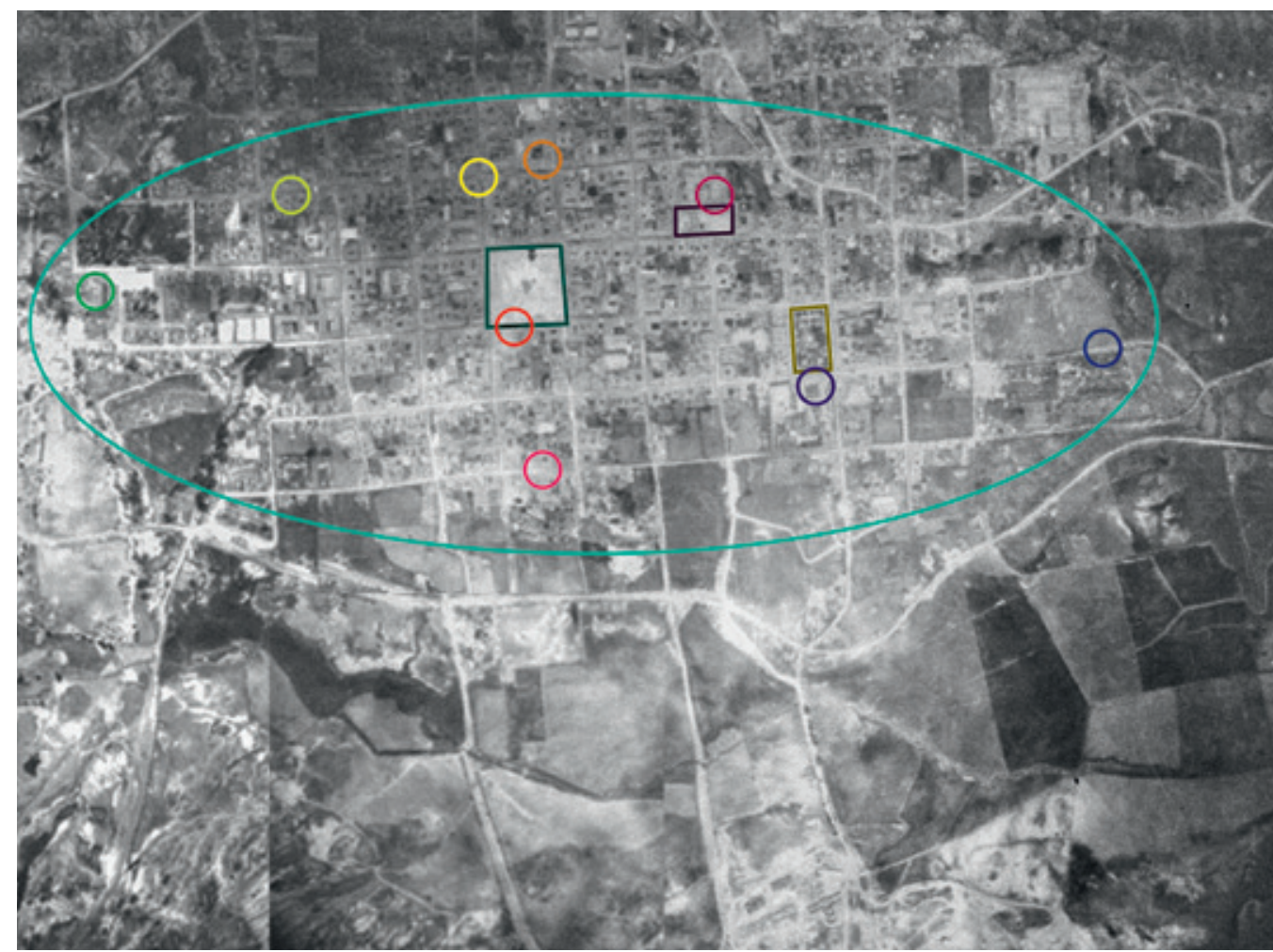

$\bigcirc$ Ermita San Laureano

Ormita Santa Bárbara

Capilla del Hospital

Templo de Santo Domingo

Templo de Santiago

Convento Santa Clara La Real

Templo de San Francisco

Templo de San Agustín

Ermita de Las Nieves Estructura urbana de Tunja
en 1610

$\square$ Plaza Principal

Placeta San Francisco

Placeta San Agustín

Imagen 6 Reconstrucción de la descripción de 1610 sobre una aerofotografía de 1939. Fuente: Autor (con base en las aerofotografías del ICAG)

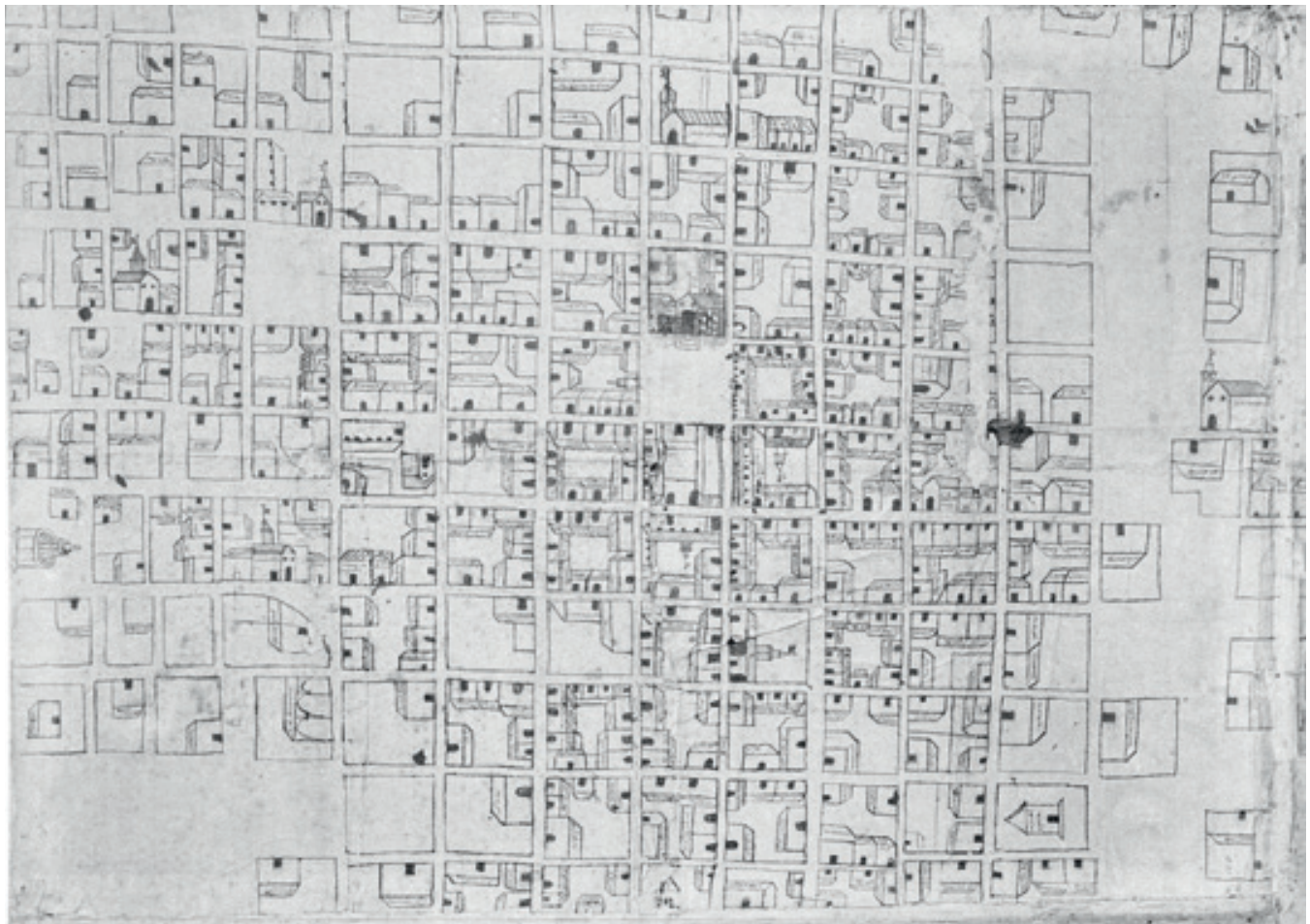

Imagen 7. Plano de Tunja de 1623. Fuente: Cartografía Histórica de los territorios Boyacenses. Banco de la República. Área Cultural Tunja. 2003 Pág. 17 


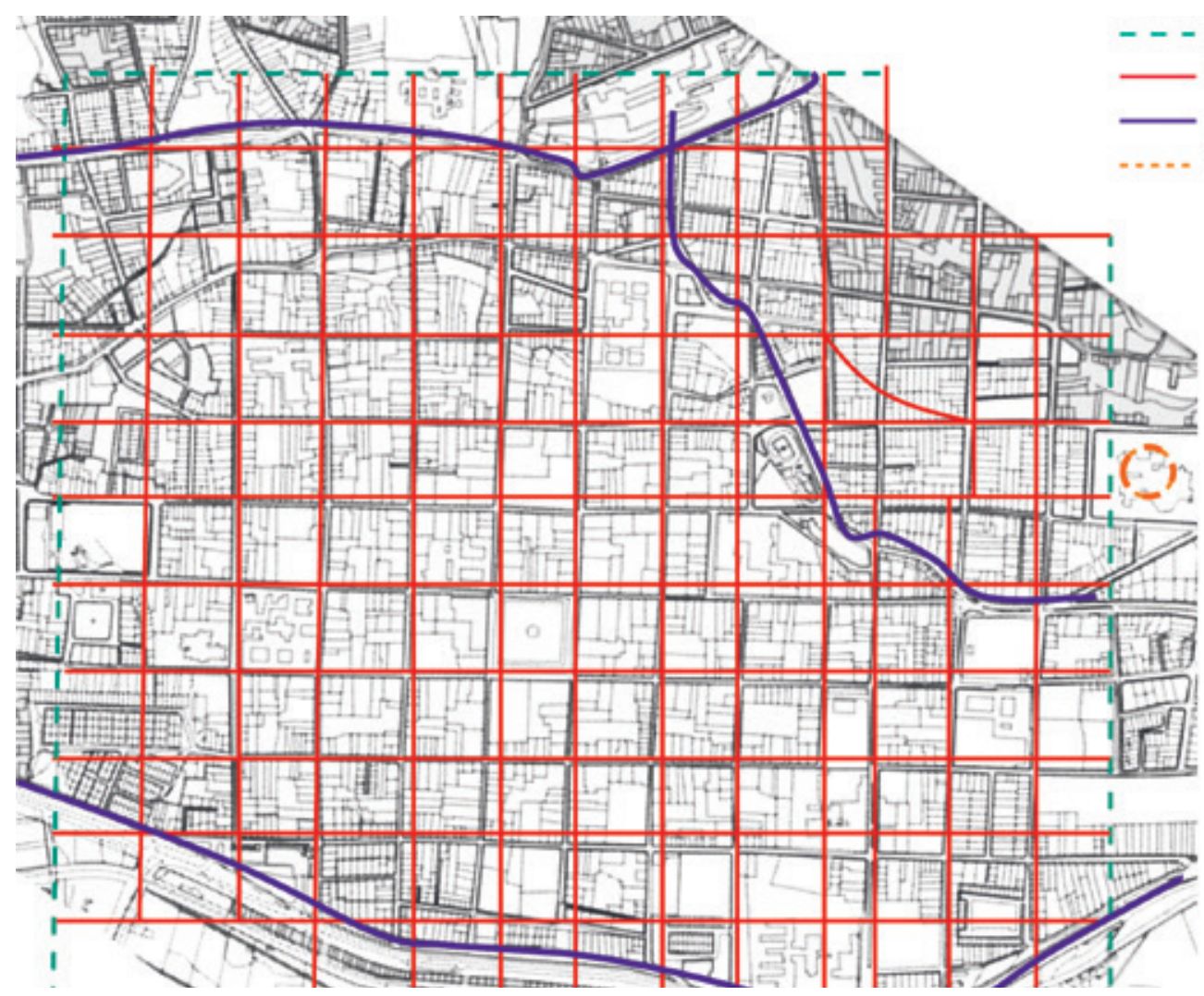

Imagen 8. Reconstrucción de la información de 1623 sobre un plano actual. Fuente: Autor sobre plano del POT Tunja

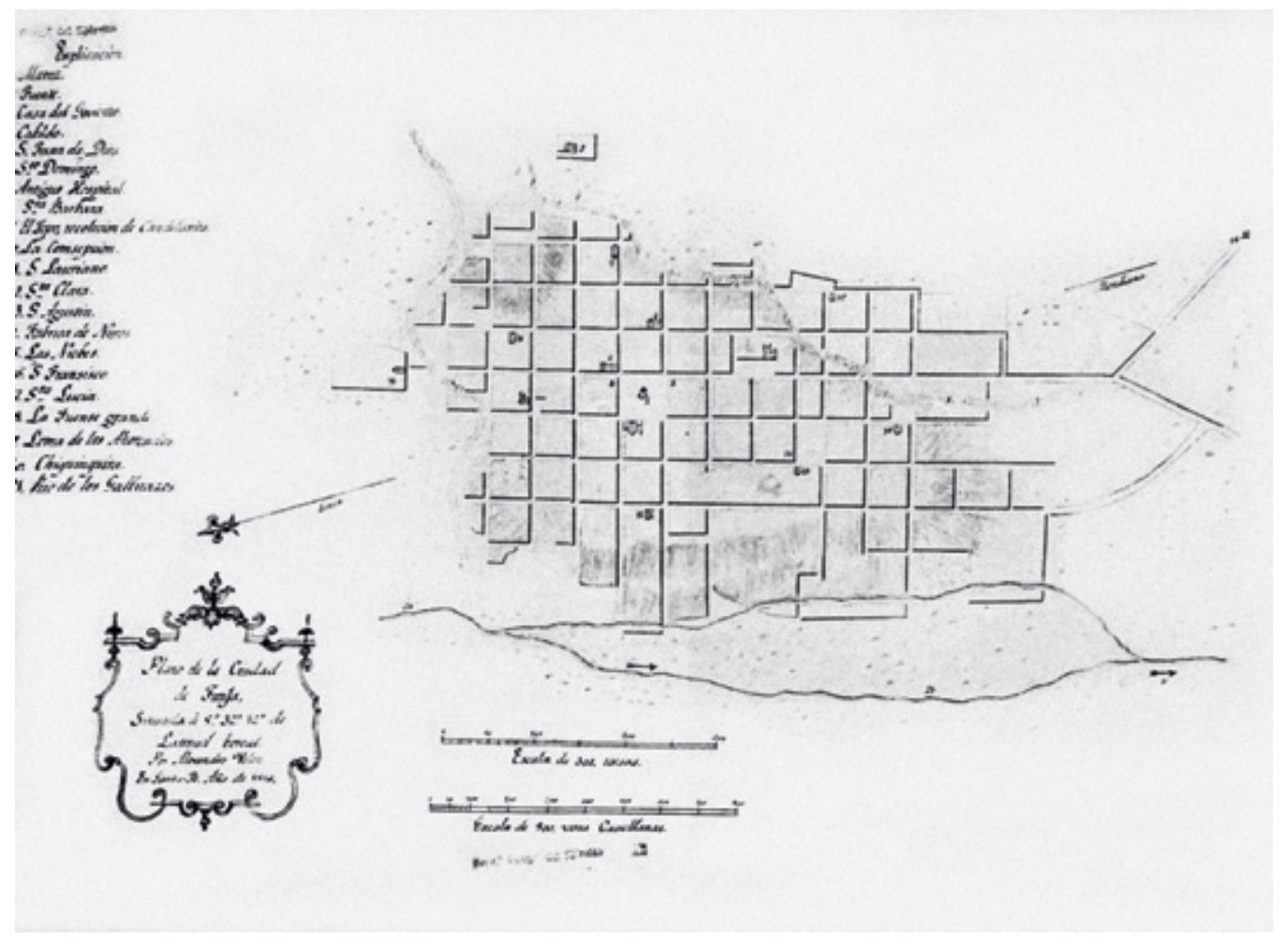

Imagen 9. Plano de Tunja de 1816. Fuente: Cartografía Histórica de los territorios Boyacenses.

Banco de la República. Área Cultural Tunja. 2003 Pág. 18 
topográficos que a la larga se han convertido en límites o bordes del centro, el plano del 23 muestra una ciudad plana, posiblemente como un signo de un anhelo de entonces.

Como evidencia cartográfica posterior (Imagen 9), se cuenta con el plano de $1816^{2}$ (Banco de la República, 2003: 18), en esa fecha Tunja tenía 277 años de fundada, en este se encuentra de una forma técnica el trazado regular de la ciudad y aparece por vez primera referenciada la condición topográfica de la ciudad (cárcavas), es decir se observan los límites topográficos naturales claramente definidos, otro aspecto de este plano es que es tal vez un indicio de lo que se llama ahora un plano de usos, pues señala el equipamiento institucional, el religioso y podría decirse que el de servicios. Este plano muestra una visión real de la ciudad, en donde la topografía es y será a lo largo de toda su historia una determinante clara en el crecimiento de la ciudad, esta imagen confirma además que el dibujo de 1623 era más una imagen idealizada o anhelada, que la ciudad real.

En el plano de 1816 aparecen marcados los usos, elementos y condiciones naturales, así:

\section{- Uso Institucional}

Casa de Gobierno

Cabildo

\section{- Uso Religioso}

Santo Domingo

Santa Bárbara

El Topo

La Concepción

San Laureano

Santa Clara

San Agustín

Las Nieves

San Francisco

Santa Lucía

\section{- Uso Servicios}

San Juan de Dios

Antiguo Hospital

Fábrica

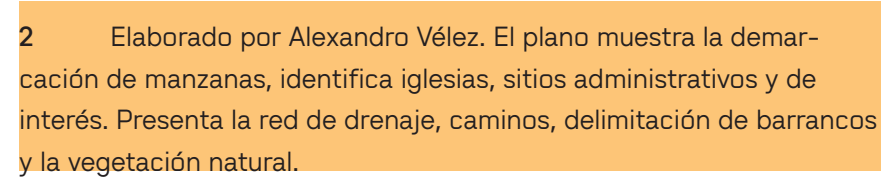

- Elementos Urbanos

Fuente (Plaza)

La Fuente Grande

\section{- Elementos Naturales}

Loma de los Ahorcados

Río de Los Gallinazos

El uso predominante en la ciudad sigue siendo el religioso, por encima de todos los demás, algunos de los templos y edificaciones nombradas aún perduran unas integras, otras con bastantes modificaciones; muchas dejaron de existir, posiblemente antes del inicio del Siglo XX. Sin embargo, es posible rastrear con precisión la ubicación de dichos elementos en la primera aerofotografía de la ciudad como puede verse en la imagen 10.

Existe, además, una carta topográfica general de 1872 (Imagen 11) en el que se observa el medio geográfico en el que se inscribe la ciudad, dentro de los diferentes cantones de lo que hoy será Boyacá, y en donde la ciudad parece marcada con el icono correspondiente a una ciudad importante: una especie de estrella circunscrita en un círculo de mayor tamaño versus los demás poblados que aparecen reseñados solo como puntos. También la palabra TUNJA aparece en letras mayúsculas en contraposición a las demás poblaciones que aparecen solo con la letra capital en mayúscula.

Después de 1900, con la aparición de la aerofotografía, el acto cartográfico cambia totalmente, de los procesos manuales dispendiosos que implicaban tomar distancias horizontales y verticales en las comisiones cartográficas, se pasa rápidamente gracias al avión, y a los avances de la fotografía a los procesos técnicos, entonces aparece por vez primera una imagen 'real' de la ciudad.

Esta imagen real de ciudad permite un acercamiento de otro tipo, ofrece la oportunidad de estudiarla de manera técnica, aparecen entonces algunos análisis especializados realizados por expertos, en los que, por ejemplo, se observan detalladamente aspectos como la morfología de la ciudad y sus etapas de crecimiento, uno de estos primeros análisis lo realiza Jorge Ayala Col (1977), quien reconstruyó planimétricamente el crecimiento de la ciudad partir de las fotografías aéreas existentes en la época. Así este tipo de estudios presentaron una nueva imagen de la ciudad que, aunque casi abstracta al mostrar, en este caso, las etapas de crecimiento, muestra también una especie de 


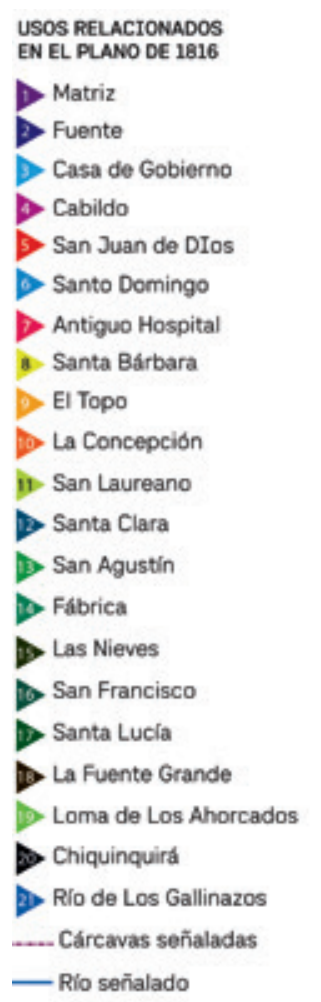

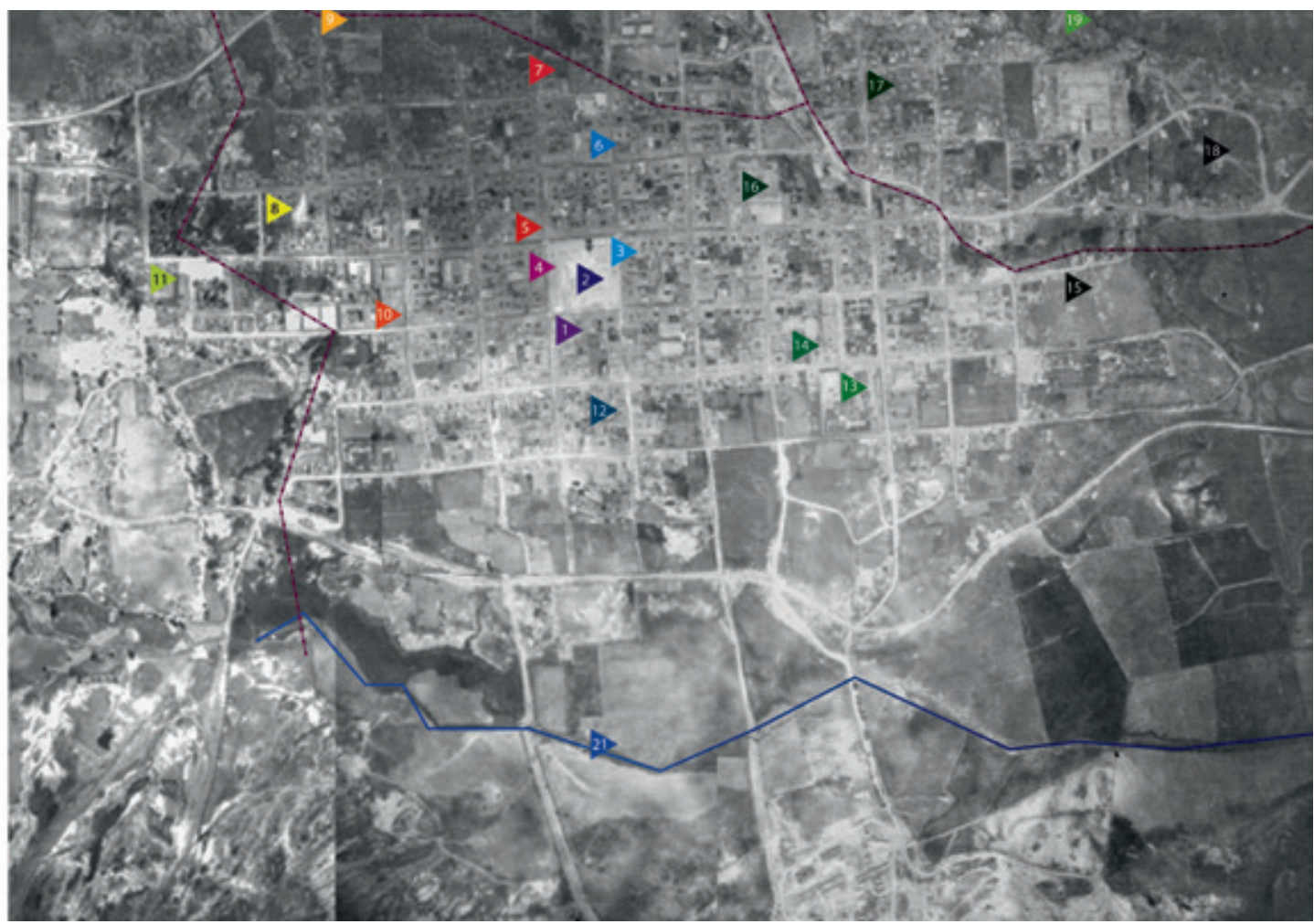

Imagen 10. Elementos señalados en el Plano de Tunja de 1816 sobre una aerofotografía de 1939. Fuente: Autor sobre una aerofotografía del IGAC.

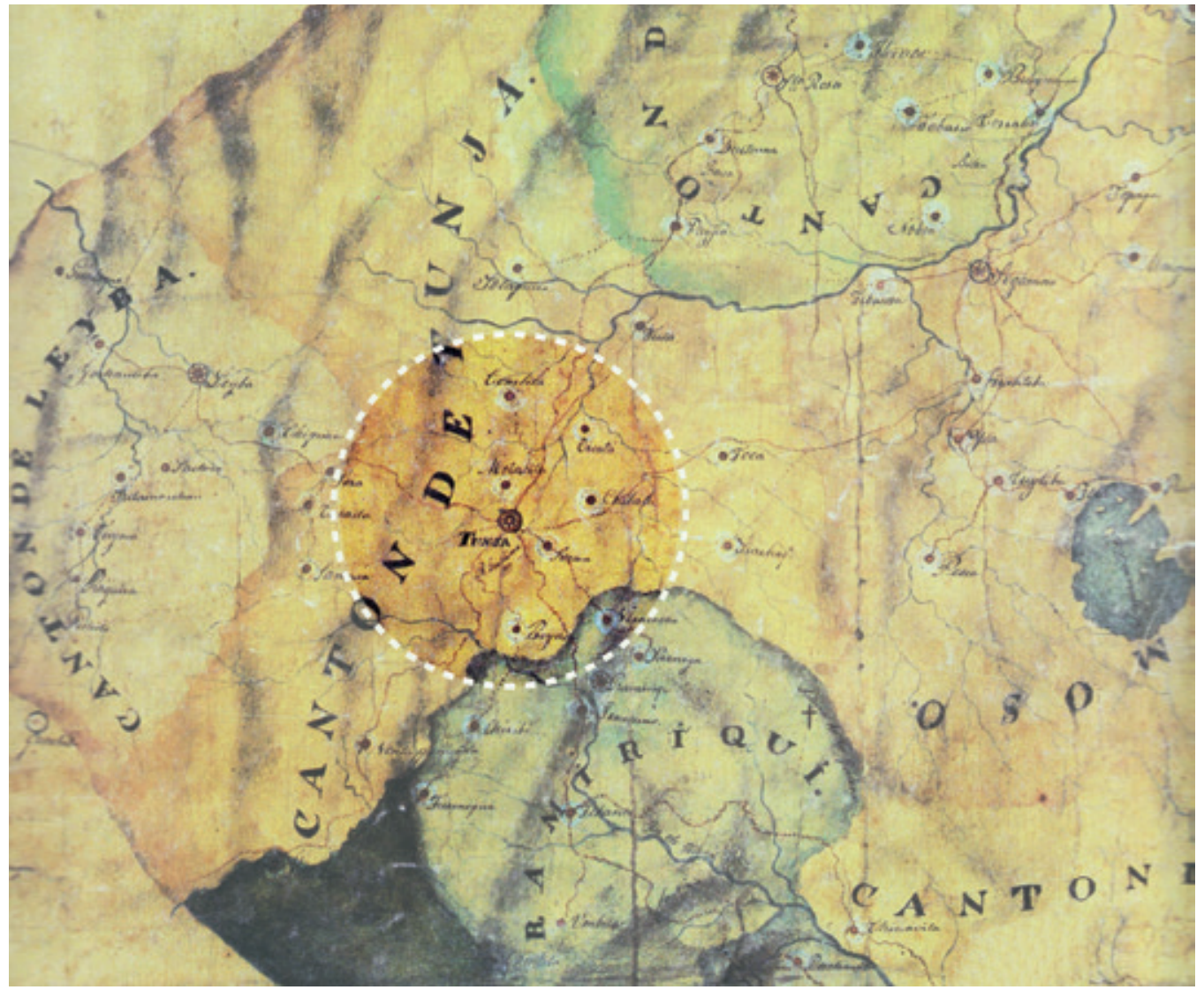

Imagen 11. Detalle de la carta topográfica de la Provincia de Tunja elaborado por J.F.M en 1872. Fuente: Revista PROA № 390 Bogotá abril 1990. 


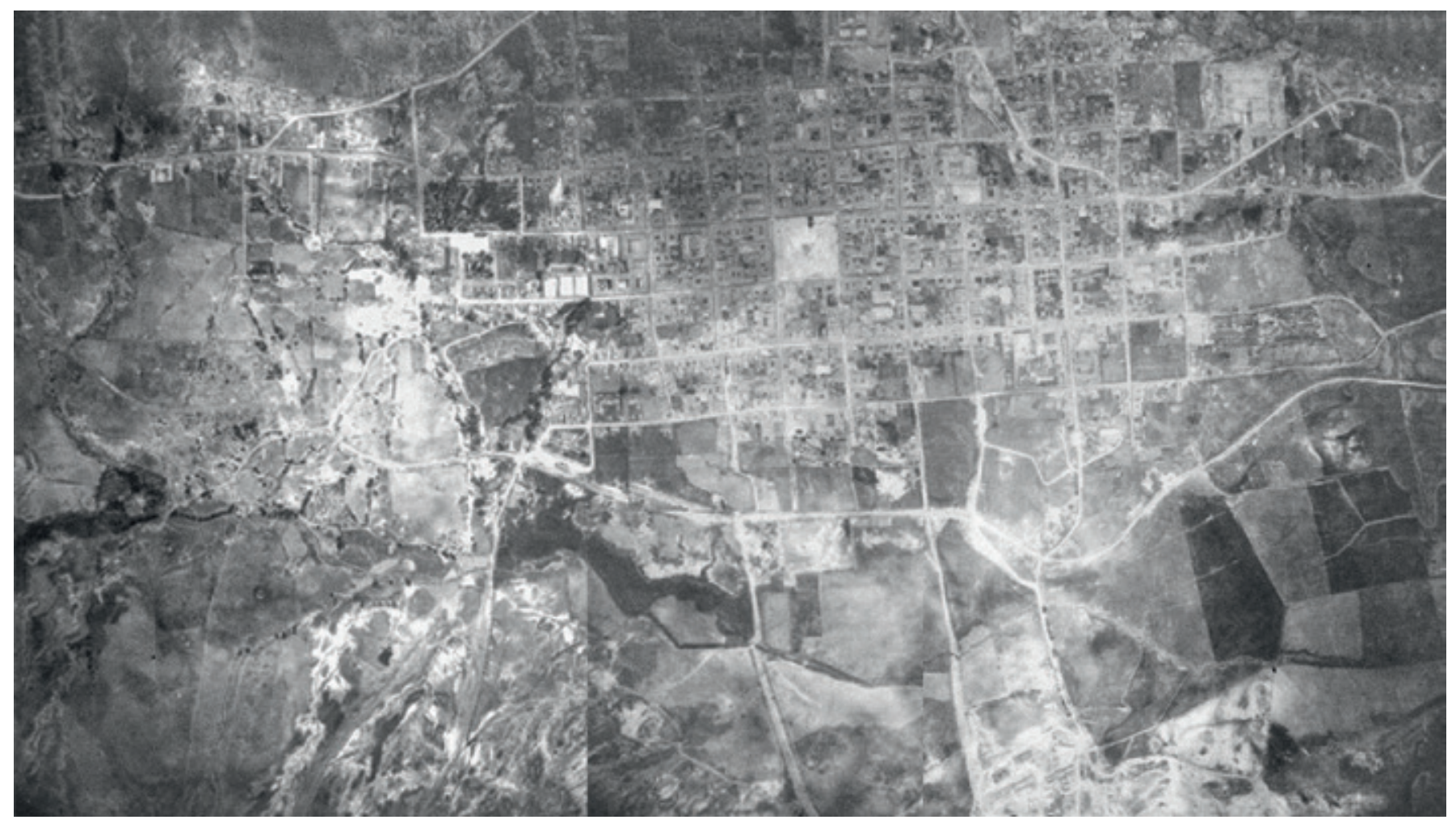

Imagen 12. Aerofotografía IGAC de Tunja 1939. Fuente IGAC

organismo que se mueve, crece, cambia, en una completamente nueva perspectiva de imagen, que abrió el camino a muchos nuevos estudios al respecto.

Esta nueva imagen de la ciudad evidencia sus límites urbanos, su tamaño, su morfología lineal específica, su espacio público, y sus dinámicas de evolución y crecimiento, desde una mirada específica: desde arriba y con un propósito claro: analizarla técnicamente.

Una vez la tecnología permitió la apropiación de la imagen de la ciudad, fácilmente y gracias a los avances en los campos de la representación gráfica, aparecen las representaciones dibujadas digitalmente de la ciudad y con estas una nueva manera de apreciar la ciudad.

La sociedad, incluso la tercermundista, adoptó, incluyó, y se apropió el concepto de lo digital en todas las formas posibles. La ciudad, como objeto a representar también con las imágenes digitalizadas de la ciudad, producto de los sistemas CAD, adquiere vida digital y puede ser fácil y rápidamente apropiada, incluso por no expertos. Además de una fácil apropiación, el medio digital permite la fácil e inmediata reproducción: ahora la imagen de la ciudad está en cualquier parte, ya no es de uso exclusivo de los expertos, los urbanistas, los arquitectos, o el gobierno, es para uso colectivo.

Esta apropiación que permiten los medios digitales hace que el concepto ciudad se vuelva fácilmente manipulable, cambiante: permite lo fragmentario, permite la mutación, y permite, como se mencionó antes, reproducción. Así, es posible que un buen porcentaje de habitantes de Tunja tengan un plano digital de la ciudad. En esa reproducción existe también un valor de identificación, pertenencia y dominio: todos podemos entender la ciudad.

\section{Otras cartografías (e = +información)}

Como parte de este nuevo concepto (lo digital) y producto de los avances, la globalización, la autopista de la información, las lecturas satelitales, etc., estamos en este momento ante un nuevo mundo en el que todos podemos ser cartógrafos, tal como lo menciona un columnista de The New York Times:

Con la ayuda de sencillas herramientas, introducidas recientemente, por compañías de Internet, millones de personas se aventuran en 


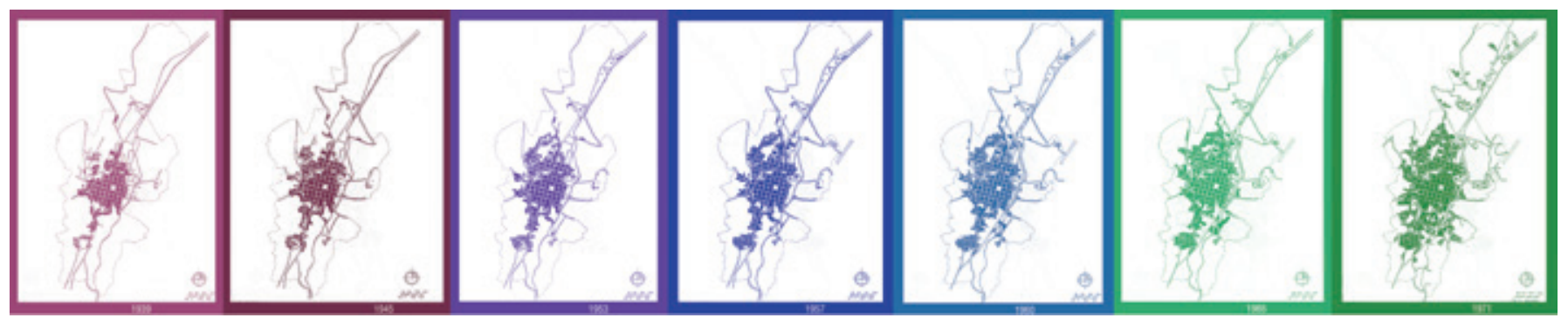

Imagen 13. Aspecto total de los estudios de crecimiento de la ciudad de Jorge Ayala desde 1939 hasta 1975 (En orden de derecha izquierda 1939, 1945, 1953, 1957, 1960, 1965,1971). Fuente: Revista APUNTES. Universidad Pontificia Javeriana. №14Marzo 1977 Pág. $22-28$.

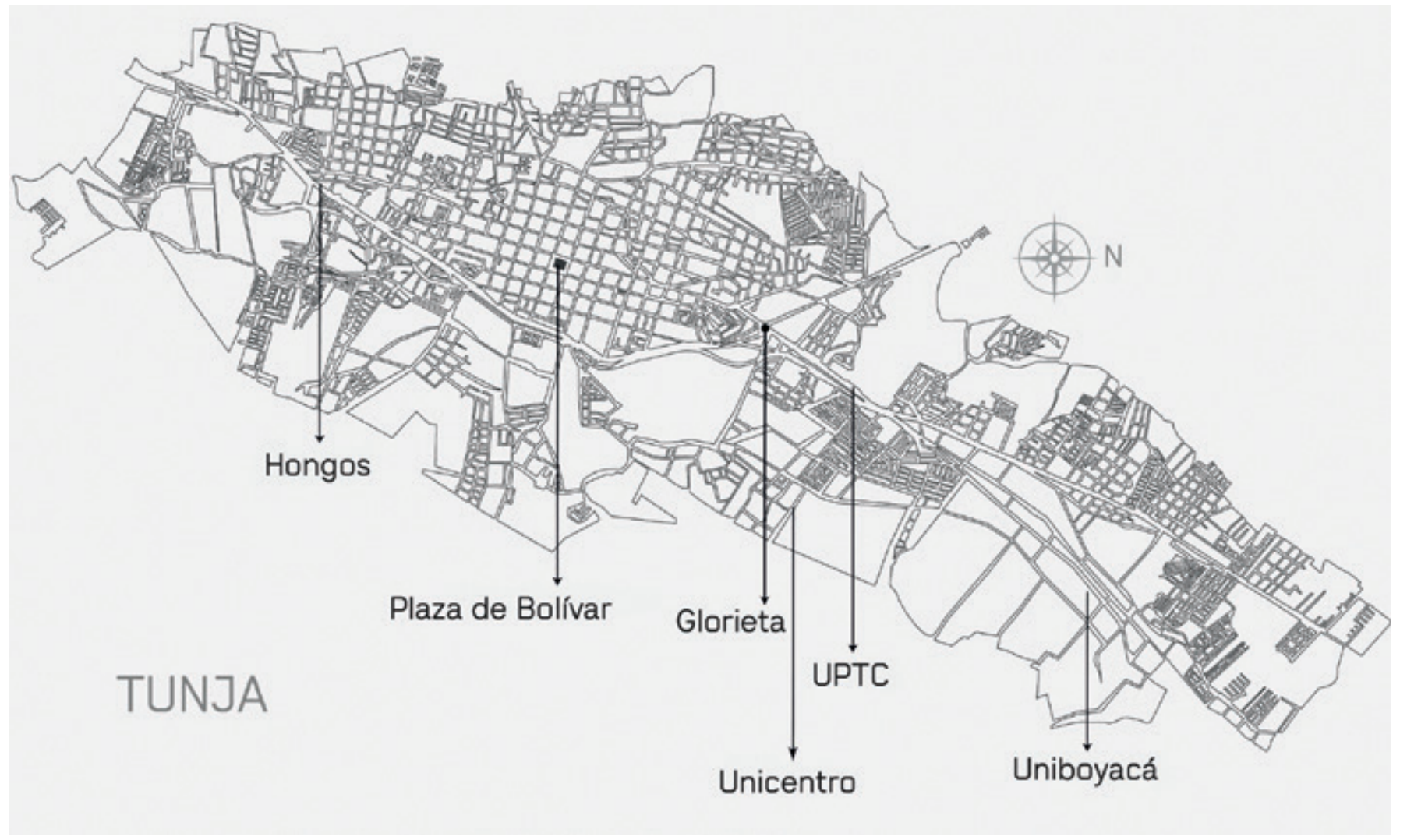

Imagen 14. Mapa vectorizado de Tunja. Fuente: Archivo Personal 


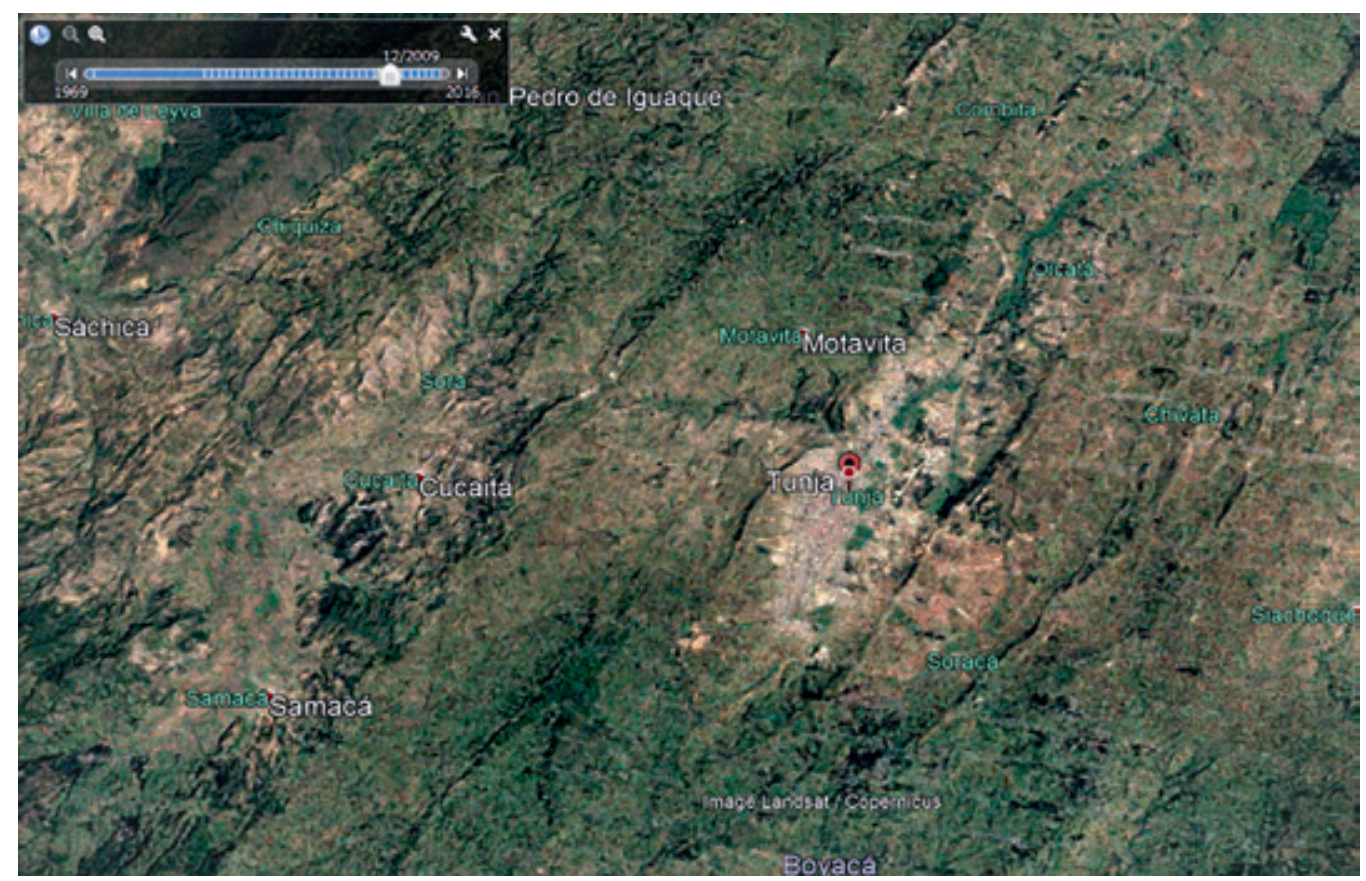

Imagen 15. Tunja en Google Earth antes del 2013 Fuente: Google Earth

la cartografía al tomar mapas digitales y añadirles anotaciones en la forma de texto, imágenes, sonido y videos. En el proceso le dan nueva forma al mundo de la cartografía y colectivamente crean una nueva clase de atlas que probablemente sea más rico y más desordenado que cualquier otro. Tomados en su totalidad, estos mapas son similares a Wikipedia, la enciclopedia en línea, en cuanto reflejan el conocimiento colectivo de millones de participantes. Los mapas trazados por esta nueva generación de cartógrafos varían desde lo útil hasta lo caprichoso y desde lo sencillo hasta lo complicado. Su precisión, como sucede con gran parte de lo que está disponible en Internet, no puede darse por sentado." (Helft, 2007)

Al parecer esta nueva posibilidad permite, como se verá en adelante, la generación de una imagen que trasciende la planimetría, en la que cada individuo ofrece su imagen de ciudad al resto que acude a la red, como en cualquier red quien dispone la información tiene la ventaja de que es, además, el que la 'vende' o manipula a su libre antojo. Entonces, al poder de manipulación de la imagen, se adiciona uno aún más potente, el poder de compartir esa imagen en una red a la que millones de millones de personas tienen acceso: la internet.

La Imagen 17 es la que ofrece uno de los buscadores de mapas más usados (Google Earth) de Tunja. Ya que en Colombia existen muy pocas ciudades con esquemas tecnológicos que permitan observar satelitalmente la ciudad de una manera muy cercana (escasamente podemos ver a Bogotá, Medellín, Cali) las demás ciudades aparecen con las referencias mínimas, aunque no se puede navegar virtualmente por la ciudad como en las que su esquema técnico lo permite, si se tiene una imagen aproximada de la forma urbana, del paisaje, del territorio en la que está inscrita, de los accidentes topográficos, etc. Pero, tal vez más interesante, son los puntos azules que brotan de la imagen de la ciudad, estos puntos, son en definitiva los que van a hablar de la ciudad desde otro ángulo, el de lo cotidiano, el del recorrido, el del acontecimiento: son fotografías que los usuarios suben a la red y que más que complementar el plano, tejen una imagen particular de ese hecho urbano llamado Tunja.

Entonces en una versión compartida desde lo real (satélite) y el acontecimiento, al dar clic sobre cada punto azul aparece sobre el mapa 'otra' imagen, la que un ciudadano quiere compartir, la que alguien desea que sea vista, la que para alguien simboliza su idea o su imagen de ciudad.

En general después de un recorrido por estas imágenes, se puede afirmar que quien ofrece su visión de ciudad lo hace con afecto, con amor por la ciudad, en la mayoría las imágenes se muestran sitios históricos, paisajes, hechos arquitectónico, nuevas construcciones, barrios, lugares de la ciudad y actos cotidianos sobre el marco urbano, en general se busca ofrecer una imagen 

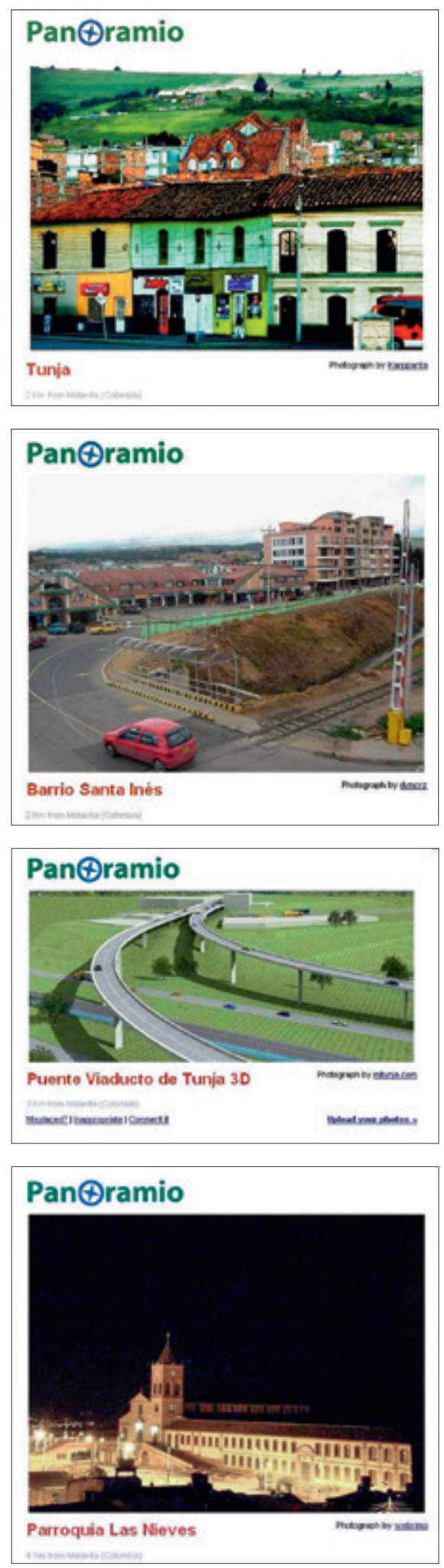
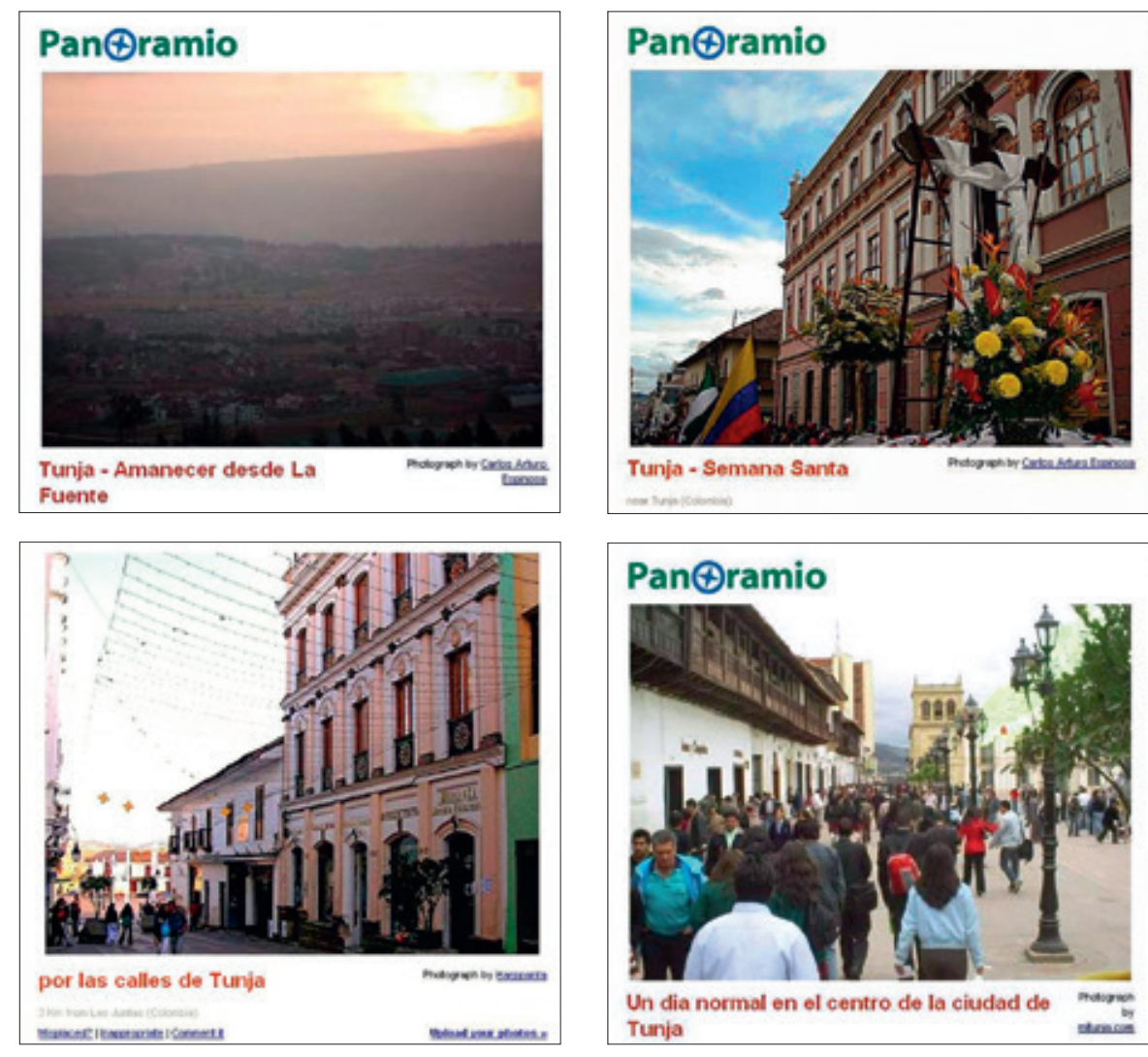

Imagen 16. Diversas imágenes colgadas en el mapa de Google Earth Historia: La casa del fundador. Lo urbano: El viaducto. Acontecimiento: Semana Santa Lo urbano: Un sector (Las Nieves). Lo bello: El paisaje. Lo urbano: (Barrio Santa Inés) Acontecimiento: La gente en la calle. Lo urbano: El centro. Un lugar: (Iglesia de las Nieves) Fuente: Google Earth 


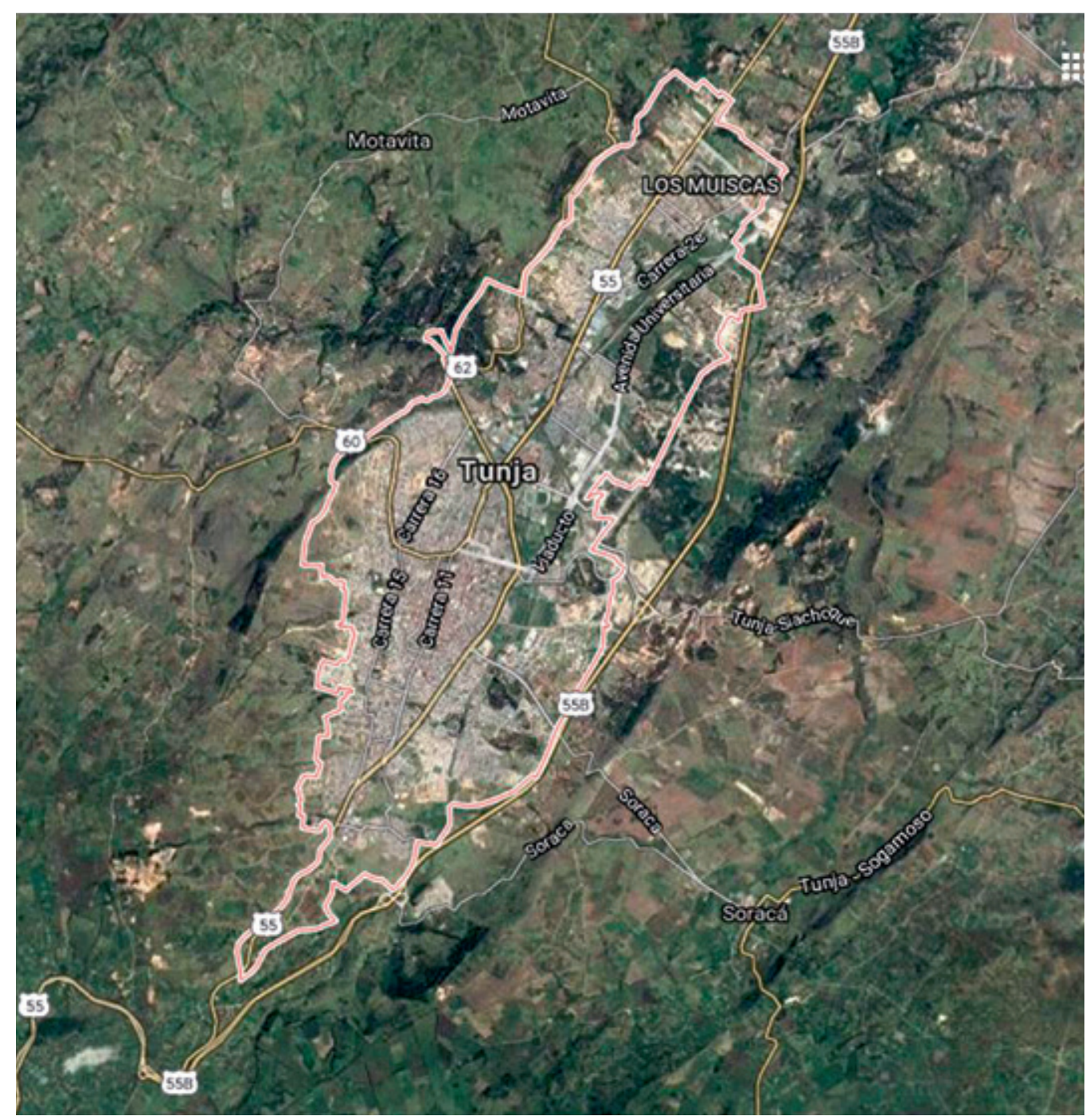

Imagen 17. La imagen real Google Earth. Fuente: Google Earth (2014)

'bella' de la ciudad. A continuación, se presenta solo una parte de las imágenes compartidas de Tunja.

La imagen ofrecida de la ciudad está referida siempre, o casi siempre, al hecho urbano, las vías, las calles, un sector, o un lugar específico; otras muestran eventos colectivos y muchos actos privados, pero todas referidas a un lugar de la ciudad, este mapa de imágenes sobre el mapa satelital es una construcción desde lo individual pero que redunda en lo colectivo, es también una imagen con una intensión estética, nadie muestra una ciudad fea, y de hecho existe una mediación emotiva en esta imagen propuesta para la red.

Por otra parte, producto también de la red, se encuentra sobre Tunja la imagen que brinda la cantidad de información, solo como un pequeño ejemplo se anotará aquí, que al teclear la palabra Tunja en el buscador de Google ${ }^{3}$, aparecen 1.910.000 resultados asociados al término en la web, y 361.000 resultados asociados a imágenes. Si se comparan los resultados de la búsqueda con una ciudad como Bogotá que tiene en información 98.300.000 resultados y en búsqueda de imágenes 985.000 resultados, se entenderá la debida proporción entre la capital y nuestra ciudad.

La red ofrece, entonces, millones de unidades de información sobre esta ciudad, pequeña ciudad, para algunos, ciudad intermedia para otros, pero con una existencia virtual definida. Esta información, en el primer caso, es de diverso tipo, desde las páginas oficiales, las noticias que mencionan tangencialmente la ciudad, las que brindan información turística, etc.; en el segundo caso (las imágenes) tienen que ver con lo que

3 Búsqueda actualizada a 2015 
se anotó antes, es un muestrario de historia, recuerdos, monumentos, eventos, acontecimientos, etc.

Finalmente, Tunja fue incluida en el proyecto Google Earth, lo que abrió una nueva dimensión a la imagen de la ciudad, mucho más cercana, más apropiable si se quiere, una ciudad bajo la modalidad Street view, que permite entonces nuevas formas de apropiación de la misma, una cartografía posible, compartida, tal vez más real que lo real, sin que entonces se deje mucho a la posibilidad de imaginar.

El mapa siempre es un reflejo de la época y de la tecnología, desde las primeras ubicaciones que denotaban la sola existencia de Tunja, hasta reconocimientos cercanos a la realidad percibida, la implementación de la técnica ayudó a clarificar la idea de una ciudad, la era digital marca por si misma otra forma de ver el mundo, otra forma de crear, generar y compartir imágenes, con el paso del tiempo está imagen técnica ha dejado de ser exclusiva y se ha vuelto colectiva y manipulable, en el momento todos podemos ser cartógrafos: armar y desarmar mapas de acuerdo a nuestra forma de ver el contexto, los próximos mapas posiblemente permitirán más interacciones, más dimensiones y más maneras de acceso a la ciudad y parafraseando a Umberto Eco (1986), más maneras también de mentir, al entender el mapa como un signo de la ciudad.

\section{Conclusiones}

La imagen es un testimonio de los significados creados sobre una realidad, en el caso de la ciudad, la imagen física, la mental y la imaginaria conforman una diversidad de nociones sobre un mismo lugar, los mapas, las descripciones, las fotografías, la historia configuran los rastros de una cartografía inacabada, la imagen de la ciudad puede complementarse día a día, no es única y finita, y los rastreos sobre el territorio siempre proveerán información sobre la realidad histórica, social, física y mental de la urbe.

Las facilidades de apropiación de la imagen de la ciudad que ha sido posible con la tecnología han permitido una multiplicidad de acercamientos que nos permiten aprehender el comportamiento del organismo urbano, y por tanto explorar y planificar el futuro desde una visión plural y sostenible. De allí que la historia permita abrir sendas e investigaciones nuevas, pues el hoy y el mañana de las ciudades estará siempre determinado por su propia historia, especialmente en América y en las ciudades fundadas luego de la conquista cuyos remanentes históricos siguen siendo vitales en la ciudad de hoy.

Las formas de representar la ciudad han pasado de la sencilla denominación, es decir de ser un nombre a sobrepasar su propia realidad, ahora podemos caminar casi por cualquier ciudad sin ni siquiera pisarla, esos cambios son los que proporcionan las nociones de ciudad que los ciudadanos configuramos.

\section{Referencias}

Academia Boyacense de Historia. (s.f.). Repertorio Boyacense. Tunja.

Banco de la República. (2003). Cartografía Histórica de los Territorios Boyacenses. Tunja: Área Cultura.

Ayala Col, J. (1977). Tunja, Conservación del Centro Histórico. Apuntes(11), 22-28.

Corradine, A. (1990). La Arquitectura en Tunja. Bogotá : Academia Boyacense de Historia- SENA.

Eco, U. (1986). La estructura ausente (3 ed.). Barcelona: Lumen.

Helft, M. (2007). Un nuevo Mundo donde todos son cartógrafos. El Tiempo. Suplemento The New York Times.

Kogan, J. (1986). Filosofía de la imaginación. Buenos Aires: Paidos Studio.

Lynch, K. (1984). La imagen de la ciudad (10a tirada 20121 ed.). Barcelona: Gustavo Gilli.

Martínez, C. (1967). Apuntes sobre el urbanismo en el nuevo Reino de Granada. Bogotá: Taller Gráfico del Banco de la República.

Pérgolis, J. C. (1998). Bogotá Fragmentada. Cultura y Espacio Urbano a fines del siglo XX. Bogotá: T/m editores.

Revista PROA. (1990). Carta Topográfica de la Provincia de Tunja. PROA (390), Carátula.

Salcedo, J. (1996). Urbanismo hispanoamericano siglos XVI-XVII-XVIII. El modelo urbano aplicado a la América española, su génesis y su desarrollo teórico y práctico. Bogotá: Pontificia Universidad Javeriana. 